\title{
How to Apply the Interactive Teaching Mode in English Translation Teaching
}

\author{
Li Xiong \\ Wuhan Donghu University, Wuhan,430212, China
}

Keywords: Interactive teaching mode, English translation, Teaching mode

\begin{abstract}
At present, the effectiveness of English translation teaching is not satisfactory, and the teaching concept of "teaching one to fish is better than giving him fish" is not yet realized in teaching due to the influence of traditional teaching ideas, therefore, the application of interactive teaching mode in English translation teaching becomes an important task in teaching. In this paper, it analyzes the application of interactive teaching mode in English translation teaching, which aims at giving full play to the role of interactive teaching mode.
\end{abstract}

\section{Introduction}

Nowadays, with the promotion and development of new curriculum reform, the traditional teaching mode of English translation teaching is unable to meet the requirements of talent cultivating today, and is more unsuitable for the student education at this stage. Therefore, English translation teaching has been given widespread concern at present, and becomes the focus of concern. However, due to the influence of traditional teaching concepts, the teaching effect of current English translation teaching can not achieve the desired teaching objectives, and many teachers still use cramming teaching methods, which have major differences from the application of interactive teaching mode in English translation. To this end, the most important task for the teachers in English translation teaching at this stage is, to give full play to the role of interactive teaching mode in teaching, and to achieve the goal of English translation teaching.

\section{Necessities of Applying the "Interactive” Teaching Mode in English Translation Teaching}

At this stage, the "interactive” teaching mode in English translation teaching is widely used, and has achieved certain teaching results. The implementation of "interactive" teaching mode has certain necessities, which are mainly the following aspects:

\section{Traditional Teaching Mode of English Translation Can not Meet the Requirements of Teaching at the Present Stage}

For students, English translation is not only a key point in learning, but also a major difficulty in learning. Students often feel powerless in translation learning and application, and are difficult for them to arouse the interest of learning English translation, resulting in that the teaching effect of English translation has been influenced seriously.

In fact, English translation is not only a "bilingual conversion process", but also an important process of training students' thinking. This requires translators not only have the ability to utilize the first language, but also have the cognitive and application ability of the second language. There is also a super-language ability between the first and second language to achieve the conversion between the two. As an important way of cultivating talents, it requires students to master various strategies and translation techniques in learning, which is also an important requirement for modern translation teaching and student learning. However, in the traditional translation teaching, teachers pay more attention to the translation process and the form of translation, but do not pay high attention to cultivating the thinking ability of students in the translation process, and even ignore the thinking ability of students. There is a fixed operating mode for adopting this teaching mode, which is generally expressed as: firstly, teachers will teach some translation skills and theoretical knowledge, then they will arrange some tasks related to English translation practice to students, so that students 
can strengthen and consolidate the translation skills in continuous translation training, and after that, they will mark and comment the translations of students one by one to give students a certain rating scale and intermediate marking evaluation, and finally, they will give the correct answer of translation. This teaching method belongs to "knowledge-imparting" teaching method, which is also a common mode of teaching in our English teaching.

The whole teaching idea of the traditional translation teaching is: teachers adopt "hand-by-hand" teaching mode to make the students study under the "hand-by-hand" teaching condition, so that students will consolidate the translation knowledge taught by teachers. Teachers do not recognize the deficiencies existed in this teaching mode, such as: on the one hand, teachers adopt this teaching mode, which mainly is to directly impart translation knowledge to students, and to forcedly fill the knowledge into students' brain, easily resulting in that students cannot master, understand and use the translation knowledge, only get some fragmented and on-sided translation knowledge, is difficult to mobilize their enthusiasm, and is difficult to stimulate their interest in learning English translation. On the other hand, in English translation teaching, the traditional translation teaching pays more attention to emphasize the "teaching" role of teachers in the classroom, and completely ignores the "learning" function of students. Therefore, firstly, it detains students to play the subjective activity, is difficult to cultivate the students' sense of innovation, and is very easy for students to lose the leaning motivation, thus affecting the effect of English translation teaching. Secondly, the traditional English translation teaching pays more attention to emphasize mastering the translation skills such as increase, decrease, separation and combination in the translation process of students, but does not give high priority to the macro control of translation process, resulting in that students are unable to think clearly in the process of translation, and the translation effect is unobvious. In summary, the traditional translation teaching has been unable to meet the requirements of teaching at the present stage, so the application of "interactive” teaching mode is imperative.

\section{Constructivist Learning Theory in English Translation Teaching}

To apply "interactive" teaching mode in English translation teaching, it needs to take the constructivist learning theory as the important basis ${ }^{[1]}$. Constructivist learning theory mainly emphasizes on taking the individual experience as the important basis to subjectively understand the objective things and the construction of meaning. In teaching, it should pay more attention to the learning process of students, and teachers are opposed to use the "cramming" teaching mode in the classroom. When applying this teaching mode to teach, the followings points are required for teachers in English translation teaching.

Firstly, teachers should clarify that the student is the important subject in the translation teaching, and in translation, the student is the initiative constructor of knowledge and skills, and is not the passive receiver of knowledge in translation teaching; while in the whole process, the teacher needs to help students, guide students and promote students to construct English translation knowledge, who is a promoter.

Secondly, the learning process of English translation mainly is the important process for students to analyze problems and take effective measures to solve problems through thinking activities, students analyze problems. Therefore, translation teaching enables students to cultivate their thinking modes and practical abilities to some extent, at the same time, if students encounter some difficulties in learning, they will solve the problem through their own efforts, which allows students to learn English translation knowledge unconsciously.

Then, learning belongs to a process of mutual assistance, so in English translation teaching, the interaction between teachers and students and the interaction between students are integral parts of learning. Learning in cooperation and interaction not only helps students to eliminate the nervous mind in learning, but also enables to create a good and harmonious learning environment for students, so that to stimulate the enthusiasm of students and make students to be more interested in learning English. 


\section{Teaching Method Analysis of "Interactive” Teaching Mode in English Translation Teaching}

"Interactive" English teaching in English translation teaching plays a positive role in promoting the English grammar teaching ${ }^{[2]}$, and the interactive language teaching method has achieved some success in English translation teaching. On the one hand, students need to combine with teaching theory in language learning and take the teaching theory as the guidance; on the other hand, teachers need to combine their own teaching characteristics and the individual differences of students in teaching, and use flexible teaching method to teach. When teachers arrange teaching activities, they need to take the student as the important center of activity arrangement, and in the interaction, and to mobilize the initiative of students in learning English translation, so as to achieve the ultimate goal of teaching English translation under the background of combining the teaching path and teaching practice. In addition, English translation teaching method should be combined with interactive English teaching method, for translation teaching activity is an important part of language teaching activity, and translation teaching itself has a certain degree of complexity, therefore, the application of interactive teaching mode is particularly important. In teaching, teachers should support and encourage students to actively participate in the classroom activities, so that to establish a good teacher-student relationship, to create a good and harmonious environment for students to learn, and to attract the attention of students.

\section{Analysis of Interactive Teaching Mode Applied in English Translation Teaching}

In English translation teaching, the application of interactive teaching mode needs to follow the constructivist learning theory, which is also an important principle insisted in the application of interactive teaching ${ }^{[3]}$, and in this process, it needs to pay more attention to emphasize the dominant position and role of students in the classroom, to focus on the cultivation of students' abilities in various aspects, and to pay attention to the cooperation between teachers and students and the cooperation between students. For this teaching mode, the main guiding idea insisted in teaching is: in the English translation classroom, teachers should focus on creating a good and harmonious classroom atmosphere for students, and guide and inspire students to participate in every step of English translation process. Through asking questions and group discussion, it can arouse students' interest in learning English, and create a good teacher-student relationship on this basis, so that students can learn more English translation knowledge under the flexible and free discussion, and master more English translation skills.

For example, after combining with the learning situation of students before class, teachers divide students into groups, so that students can cooperate and learn with each other. Teachers can use the guiding-teaching method to introduce the main teaching content of this class, for example, when learning the translation of tourism knowledge, teachers can ask students to discuss in groups, summarize the places they want to travel and the essential goods they need to carry in English, and then recommend one representative each group to express. As a result, it not only cultivates the communication skills of teachers, but also effectively introduces the content teachers need to teach. Such kind of way makes it easier for students to accept the English translation knowledge they are going to learn, deepen their understanding in learning English, and have a better grasp of English translation and learning skills. In addition, in the classroom, teacher should pay attention to the three important aspects of English translation: understanding, conversion and expression. In the three aspects, it should give full play to the dominant role of students, guide students to participate in learning activities, and improve their English translation ability in constant communications.

In English translation classroom, if teachers want to effectively improve the teaching effectiveness and the quality of teaching, they should pay attention to the role of guidance when students are previewing the textbook ${ }^{[4]}$, so that to avoid directly imparting the knowledge and English translation skills to students, and to stimulate students to actively participate in learning English translation activities. When teacher set up problems for students, they need to classify problems, and gradually, students will master the English translation skills of one category, and will translate with great facility. For example, in terms of text interpretation, teachers can guide students to understand the text through 
questions. This requires teachers to focus on one translation theory of articles, guide students from the shallower to the deeper, indicate some basic ideas for students to understand and translate articles, and set up different priorities for different translations.

\section{Case Analysis on the Construction of Interactive Mode in English Translation}

Taking the first lesion of A Textbook of English-Chinese and Chinese-English Translation as a case of English interactive mode construction, it constructs a better interactive translation teaching mode. This lesson is mainly about NO Giant Skyscrapers, in which the main information of this article passed to students are the translation of "have to be" and "country" and the corresponding knowledge points. In general, students will translate the two words in to “不得不” and “国家”, so instead of directly telling the meaning of the two words to students, teachers should be fully prepared before teaching, and set up a number of related questions to guide students' thinking.

For example, teachers can set a question according to "have to be", such as which word is related to this phrase, such as famous, for their beauty or their historical importance. And they require students to find the grammar of this phrase by themselves, and understand its concepts, For "country", students can ask students questions: "What this word means?", and require students to observe whether an article is applied to this word.

Students answer these question through their own efforts, which not only can consolidate the knowledge in translation ${ }^{[5]}$, but also can understand the information center of words to build a correct, surefooted and careful attitude of English translation, so that to learn the English translation very well. At the same time, teachers need to make students pay attention to the features of translation, carefully analyze and study the different viewpoints of students presented in English-Chinese translation, adopt different teaching modes according to the actual situation of students, ensure students to have a good ability of mastering languages, and solve problems of language translation from the understanding. As a result, it is very easy for students to mater the knowledge and skills in it, so the quality of English translation teaching also increases, so that to promote the development of our society continuously under the premise of meeting the students' desire to learn.

\section{Summary}

In this paper, from the necessity of applying the "interactive" teaching mode in English translation teaching, teaching method analysis of "interactive" teaching mode in English translation teaching, and the analysis of interactive teaching mode applied in English translation teaching, it is clear that the traditional teaching method in English translation teaching at the present stage can not meet the requirements of student learning, and even can not meet the requirements of social development towards talents. To this end, the application of interactive teaching mode of English translation teaching at present has become an inevitable trend. Interactive English teaching pays more attention to the role of students in the learning process, focuses on the cultivation of students' abilities in various aspects, encourages teachers to focus on the interactions between students in teaching, and encourages the cooperation between students. In English translation teaching, teachers need to create a good and harmonious learning atmosphere for students, ensure that students can learn English translation very well under such kind of learning atmosphere, and improve the teaching effectiveness and quality of English translation teaching classroom, so that to meet the requirements of social development.

\section{Acknowledgments}

Topic of this paper: Curriculum Optimization Research and Practice of College Translation Major Based on the Needs Analysis. No. 150007. 


\section{References}

[1] Wang Xiaoyan. Application Research of Metaphor Theory in English Translation Teaching. Overseas English, 2014,3(11):32-33.

[2] Su Xiuyun. Brief Analysis on the Interactive Teaching Mode of Business English Translation. Brand, 2013,4(7):64-78.

[3] Li Honglv. On the Application of Interactive Translation Teaching Model for English Majors. Journal of Huaihua University, 2014,5(9):126-128.

[4] Ding Yingjun. Practice on Computer Aided Interactive Translation Teaching Model. Journal of Changsha Telecommunications and Technology Vocational College, 2010,09(2):108-111.

[5] Yang Xuejing. Construction and Application of Interactive Translation Teaching Mode and Cultural Module in the Translation Training of Advanced English Class. Journal of Changchun Education Institute, 2015,2(3):107-108. 